\title{
PATRIOTISM AND FRIENDSHIP OF PEOPLES AS THE BASIC DETERMINANTS OF THE RUSSIAN CIVILIZATION
}

\author{
Richard A. Danakari \\ Volgograd Institute of Management, Branch of Russian Presidential Academy \\ of National Economy and Public Administration, Volgograd, Russian Federation
}

\begin{abstract}
Introduction. The article examines the nature and essence of patriotism and friendship of peoples, their crucial role for the life of the Russian Federation. Over the past decades, radical changes have taken place in the political system of Russia, its social and ethnic structure, and a heterogeneous ethno-confessional society has been formed. The author shows that patriotism and friendship of peoples are the most important determinants, specific properties necessary for the integration of our multinational federation ensuring order and stability in the country, its sustainable and dynamic development, the gradual formation of new supra-ethnic and supra-confessional values, and general cultural identity. Methods. The combination of applying methods and approaches is the key to studying the theory and practice of patriotism, recognizing its procedural nature, unity and opposition in the activities of the state and society, the interests of the government, political parties and social groups. The use of the polyparadigmatic methodology in studying the nature and essence of patriotism, in particular, the activity and civilizational approaches, the synergetic method, dialectic categories made it possible to determine the complexity and continuity of the formation of patriotism and patriotic work, to reveal dynamism and conflict, general and special features in them. Analysis. Studying the real state of Russian society points to the weakness of systemic activities of patriotic education, preserving and strengthening the unity and friendship between nations. The lack of a common goal problematizes the search for a common patriotic idea, new foundations for Russian civilization, the common existence of nations, the construction of a welfare state and a harmonious society. Results. The article reveals inadequacy of the declared ideas of patriotism and friendship of peoples to the policy and practice of implementing neoliberal values and the priority of individualism. The author shows that the process of further fragmentation and stratification, alienation and separation of people according to racial, national, ethnic, cultural, religious, confessional, generational, professional and other characteristics continues in society. The transition of already atomized individuals from the ethnic mentality and national behavioral stereotypes to a single patriotic goal - the all-Russian identity - is formal. Today, the activity on the formation of patriotism and patriotic attitudes of consciousness does not affect the deep, essential foundations of society, is of a festival and manipulative nature, and in many respects concerns only the military sphere, tourism and sports. The notes mentioned create significant difficulties in understanding the idea of the common welfare, genuine and false in patriotism, the definition of objective interests of the state, authority and society, social groups and individual elites. Modern globalization inevitably involves taking into account the national interests of Russia, the search for optimal forms of interconnection of civilizational and universal principles.
\end{abstract}

Key words: globalization, national politics, patriotism, friendship of nations, common cultural identity.

Citation. Danakari R.A. Patriotism and Friendship of Peoples as the Basic Determinants of the Russian Civilization. Vestnik Volgogradskogo gosudarstvennogo universiteta. Seriya 4. Istoriya. Regionovedenie. Mezhdunarodnye otnosheniya [Science Journal of Volgograd State University. History. Area Studies. International Relations], 2019, vol. 24, no. 5, pp. 193-204. (in Russian). DOI: https://doi.org/10.15688/jvolsu4.2019.5.14

УДК 325.1

Дата поступления статьи: 01.12.2018

ББК $66.021+60.723 .5$

Дата принятия статьи: 01.07.2019

\section{ПАТРИОТИЗМ И ДРУЖБА НАРОДОВ КАК БАЗИСНЫЕ ДЕТЕРМИНАНТЫ РОССИЙСКОЙ ЦИВИЛИЗАЦИИ}

\author{
Ричард Арами Данакари \\ Волгоградский институт управления - филиал Российской академии народного хозяйства \\ и государственной службы при Президенте РФ, г. Волгоград, Российская Федерация
}


Аннотация. Введение. В статье исследуется природа и сущность патриотизма и дружбы народов, их судьбоносное значение для бытия Российской Федерации. За последние десятилетия произошли радикальные изменения в политической системе России, ее социальной и этнической структуре, сформировался гетерогенный этноконфессиональный социум. Автор показывает, что патриотизм и дружба народов - важнейшие детерминанты, специфические свойства, необходимые для интеграции нашей многонациональной федерации, обеспечения порядка и стабильности в стране, ее устойчивого и динамичного развития, постепенного формирования новых надэтнических и надконфессиональных ценностей, общекультурной идентичности. Meтодbl. Совокупность применения методов и подходов - это ключ к исследованию теории и практики патриотизма, признание его процессуального характера, единства и противоположности в деятельности государства и общества, интересов власти, политических партий и социальных групп. Использование полипарадигмальной методологии при изучении природы и сущности патриотизма, в частности, деятельностного и цивилизационного подходов, синергетического метода, категорий диалектики позволили определить сложность и непрерывность формирования патриотизма и патриотической работы, выявить в них динамизм и конфликтность, общее и особенное. Анализ. Исследование реального состояния российского общества указывает на слабость системной деятельности по патриотическому воспитанию, сохранению и укреплению единства и дружбы между народами. Отсутствие единой цели проблематизирует поиск общепатриотической идеи, новых базовых оснований для российской цивилизации, совместного бытия народов, строительства социального государства и гармоничного общества. Результаты. Выявлена неадекватность декларируемых идей патриотизма и дружбы народов в политике и практике реализации неолиберальных ценностей, приоритетности индивидуализма. Показано, что в обществе продолжается процесс дальнейшей фрагментации и расслоения, отчуждения и разделения людей по расовым, национальным, этническим, культурным, религиозным, конфессиональным, поколенческим, профессиональным и иным признакам. Является формальным переход уже атомизировавшихся индивидов от этнической ментальности и национальных стереотипов поведения к единой патриотической цели - общероссийской идентичности. Сегодня деятельность по формированию патриотизма и патриотических установок сознания не затрагивает глубинные, сущностные основания общества, носит фестивальный и манипулятивный характер, касается во многом лишь военной сферы, туризма и спорта. Все это создает значительные трудности в понимании идеи общего блага, подлинного и ложного в патриотизме, определении объективных интересов государства, власти и общества, социальных групп и отдельных элит. Современная глобализация с неизбежностью предполагает учет национальных интересов России, поиск оптимальных форм взаимосвязи цивилизационного и общечеловеческого начал.

Ключевые слова: глобализация, национальная политика, патриотизм, дружба народов, общекультурная идентичность.

Цитирование. Данакари Р. А. Патриотизм и дружба народов как базисные детерминанты российской цивилизации // Вестник Волгоградского государственного университета. Серия 4, История. Регионоведение. Международные отношения. - 2019. - Т. 24, № 5. - С. 193-204. - DOI: https://doi.org/10.15688/jvolsu4.2019.5.14

Введение. В современной России актуальной задачей стало формирование патриотических ценностей и культуры общенационального единства. За последние годы тема патриотизма и проблема патриотического воспитания оказались в центре внимания государственной политики, научного сообщества и общественного сознания. Исторический опыт и социально-политическая практика России показывают, что сфера патриотизма всегда была прерогативой государства и власти разных уровней.

В статье предлагается раскрыть слабые звенья в сфере государственного управления и деятельности гражданского общества, не позволяющие осуществить эффективную системную и систематическую работу по пат- риотическому воспитанию. Соответственно, цель исследования - анализ бытия и специфики функционирования российского социума, определение патриотизма и дружбы народов как основных детерминант, неотъемлемых свойств, основы объединительной идеи для нашего полиэтнического и поликонфессионального сообщества наций и этносов, их интеграции в единую целостность.

За последние четверть века в постсоветской России произошли радикальные изменения в политической и социально-этнической структуре общества, сформировался гетерогенный этноконфессиональный социум. Однако на периферии реальной политики оказалась задача по формированию новых надэтнических и надконфессиональных ценностей, столь 
необходимых для интеграции, общенационального единства, обеспечения порядка и устойчивого развития страны. Ныне востребована объективная аналитика состояния нашего общества, диагноз и определение путей перехода разных групп и уже атомизированных индивидов, представителей разных народов, от этнической идентичности и национальных стереотипов к единой цели, общероссийской идентичности. Все более актуальный характер приобретает еще одна исследовательская задача: определение объективных, базовых ценностей российской цивилизации, выявление их роли и места в системе совместного бытия народов, гармоничного развития в будущем.

В непрерывно меняющихся условиях действительности также огромное теоретическое и практическое значение имеют ответы на вопросы: что такое патриотизм, каковы его роль и место в современном обществе, в чем особенности российского патриотизма? В этой связи актуальный характер приобретает знание природы и сущности патриотизма, его специфики и исторической роли в жизнедеятельности народов России, отдельных людей. Важно понимание того, что такое Российская Федерация и каковы перспективы ее развития как поликонфессиональной и многонациональной страны, федерации народов?

В последние годы на разных уровнях власти: федеральном, региональном и муниципальном началась активная работа по изучению патриотизма и патриотического воспитания населения. Стало очевидно, что решение задач политического, социально-экономического и культурного развития страны невозможно без обеспечения мира и согласия, единства многонационального и поликонфессионального общества.

Сегодня, в условиях глобализации мира и активного развития транснациональных хозяйственных связей, одна из важнейших и актуальных задач нашего многонационального государства и общества - это формирование российского патриотизма и ценностей, связанных с идеями единства и дружбы народов. Они имеют огромное политическое значение в воспитании людей, особенно молодого поколения, в духе подлинных чувств любви к Родине, признания священности страны, родного очага. Именно работа по воспитанию патриотов - физически и духовно здоровых людей, сможет создать атмосферу уверенности в настоящем и будущем, открыть пути для динамичного развития страны, обеспечить создание сильной России как конкурентоспособной мировой державы.

Методы исследования. В рамках системной методологии возможно наиболее глубокое и объективное теоретическое и практическое исследование реальной действительности, в том числе проблемы патриотизма и дружбы народов. Такая работа позволит значительно увеличить границы познания и расширить пространство научного поиска. Изучение патриотизма и реализация установок патриотического сознания во многом являются сложным процессом. Они связаны с тем, что современная политика, общественные отношения представляют собой системную и динамическую сущность, в которой действуют разнородные политические силы, социальные и этнические группы, имеющие многообразные и противоречивые, а порою и конфликтные интересы. Анализ патриотизма и уровня развитости ее установок с позиций системного подхода и принципа холизма как целостности свидетельствует о слабой адекватности интересов российского государства и ее элиты, власти разных уровней и гражданского общества, наличии напряженности и конфликтности в их взаимодействии, отсутствии комплексности.

Рассматривая вопросы патриотизма и патриотической работы с позиций форм и методов современного глобализма, следует указать на недостаточно высокий уровень развитости патриотического сознания российской бюрократии, элиты, части общества. Не секрет, что сегодня многое в этой деятельности зависит не только от реакции руководства страны на «вызовы» глобализации, авторитета нашей власти на международной арене, но и во многом от решений федеральной и региональной власти в области внутренней политики.

Изменения в политической, социальноэкономической, культурной и иных сферах жизни часто не сопровождаются соответствующими реальными шагами по реформированию региональных и муниципальных структур власти, адекватных современным вызовам. 
В свою очередь, само государство, используя неразвитость и просчеты российского мультикультурного гражданского общества, непрерывно укрепляет вертикаль власти, увеличивает свою мощь и силу, часто забывая о том, что главная его цель - служение общему благу. Зачастую взаимодействие местных органов власти и управления в данной сфере носит формальный и показной характер. Консерватизм в работе органов федеральной и региональной власти проявляется в том, что исключительно только себя они считают основным субъектом патриотизма и патриотической деятельности. Не принимается во внимание и то, что значительная работа по патриотическому воспитанию касается местной власти и общественных организаций, сферы их коммуникаций и взаимодействия, образования и воспитания, диалога людей разных наций и этносов, религий и конфессий на местном уровне.

Использование деятельностного и цивилизационного подходов способствует получению более объективных и полных знаний о патриотизме. Они помогают выявить механизмы функционирования государства как субъекта патриотизма, а многонациональное и поликультурное общество рассматривать как объект данного вида деятельности, на который направлено действие властных структур разных уровней и общественных организаций. Предметом исследования окажутся свойства, стороны, специфика, проблемы и сложности патриотической работы.

При исследовании патриотизма плодотворны и эвристичны компаративистский анализ, конструктивистский и инструменталистский подходы. Они позволяют выявить реальных субъектов и объектов, организаторов, участников и активистов работы в сфере патриотизма. В частности, сравнительный анализ позволяет найти общее и особенное в деятельности разных уровней власти, сходства и различия в работе общественных организаций, особенно национальных центров и землячеств по патриотическому воспитанию. Создание моделей, конструктов позволяет увидеть и ощутить многие грани бытия, «вживаться» в реальность, определить динамику процесса не только с формальной, внешней стороны, но как бы и изнутри.
Патриотизм как политический и общественный феномен можно рассматривать с позиций герменевтики и феноменологической методологии. В результате патриотизм воспринимается как уникальный гипертекст, особая метафизика бытия общества и человека, «жизненный мир» людей со своими осознанными ценностями, неосознанной волей и страстями, традициями и артефактами. В нем «присутствуют», выявляются стремления и позиции властных структур всех уровней, мировоззренческие установки и деятельность социальных и этнических, поколенческих и гендерных групп, разных слоев, что позволяет увидеть более объемную и качественную картину реальности.

Дискуссия. За последние годы в российской политической и социальной науке изучению патриотизма, взаимодействию властных и управленческих структур, общественных организаций и диаспор в данной сфере уделяется большое значение. Правда, в практических исследованиях все еще открытым остается вопрос об эффективности патриотической работы, результативности деятельности по повышению уровня патриотизма и качества патриотического сознания граждан, особенно у молодежи.

Рассматривая историю проблемы, отметим, что многие представители мировой и отечественной науки и культуры, государственные и общественные деятели, писатели и публицисты обращались к вопросу патриотизма, теме патриотического воспитания, особенностям формирования этнической идентичности и национальных традиций. Патриотизм, как идея и понятие, имеет давнюю историческую, политическую, философскую и иные традиции, интерпретируется в разных смыслах.

В философском энциклопедическом словаре понятие патриотизм (от греч. patris соотечественник, родина, отечество) - это любовь к отечеству, преданность ему, стремление своими действиями служить его интересам $[17$, с. 484$]$.

В каждую историческую эпоху патриотизм имел свой политический и социальный смысл, культурное значение, нравственное и ценностное содержание. Мыслители античного мира Платон, Аристотель, Цицерон, а за- 
тем и эпохи Нового времени, в частности, философы немецкой классики И. Кант, Г. Гегель, в системе ценностей и нравственных обязанностей членов общества немалую роль отводили патриотизму. Несмотря на различия в исторических, политических и философских взглядах, многие из них были едины во мнении об Отечестве, указывали на неразрывную связь патриотизма и политики, деятельности людей и их патриотических чувств.

И. Кант и Г. Гегель связывали патриотизм с правами и свободами человека, чувством доверия граждан к государству. В частности, И. Кант, опираясь на универсальные принципы права, провозглашает: «...поступай внешне так, чтобы свободное проявление твоего произвола было совместимо со свободой каждого, сообразной с всеобщим законом» [9, c. 140]. В свою очередь, Г. Гегель отмечал: «Патриотизм основывается на сознании абсолютного государства. Такое умонастроение, готовность отдать свое достояние и жизнь ради целого в народе тем больше, чем больше отдельный человек может ради общего дела действовать по собственной воле и самостоятельно и чем больше доверия испытывает он к государству» [5, с. 70]. Таким образом, патриотизм и вопросы патриотического воспитания в немецкой классической философии непосредственно связывались со всеобщими правами человека, где он рассматривался не как средство, а как высшая ценность.

Тема патриотизма занимает особое место в истории России, научной, общественнополитической и литературной деятельности представителей русского Просвещения, революционно-демократической мысли и религиозной философии. В своих трудах М.В. Ломоносов, Н.М. Карамзин, А.Н. Радищев, В.Г. Белинский, Н.Г. Чернышевский, В.С. Соловьев, Н.А. Бердяев и другие, размышляя о патриотизме, отношении к Отечеству, считали его одним из главных в своей жизни и научном творчестве.

Великий русский ученый М.В. Ломоносов слово «гражданин» считал синонимом понятия «патриот», связывал их с историческими и социальными условиями жизни, уровнем развития общества. Для него они включали высокую нравственность, служение на благо России, любовь к знаниям [13, с. 327].
Известный историк и литератор Н.М. Карамзин выделял три составляющие части патриотизма. Во-первых, это физическая любовь к Родине, месту, где человек родился и вырос. Во-вторых, любовь гражданская, под которой понимается социальная связь человека с обществом, комплексом прав, свобод и обязанностей. В-третьих, любовь политическая, то есть человек поддерживает и осуществляет в своей деятельности политические идеалы Родины [10, с. 34].

В трудах А.Н. Радищева утверждается, что истинный сын Отечества тот, кто служит своему народу и стремится к справедливости. В статье «Беседа о том, что есть сын Отечества» он писал о том, что патриотом может быть только «существо свободное, поелику одарено умом, разумом и свободною волею» [15, с. 214].

Известный критик В.Г. Белинский писал: «...всякая благородная личность глубоко осознает свое кровное родство, свои кровные связи с Отечеством... Живой человек носит в своем духе, своем сердце, в своей крови жизнь общества: он болеет его недугами, мучится его страданиями, цветет его здоровьем, блаженствует его счастьем, вне своих собственных, своих личных обстоятельств» [2, с. 163]. В общественной деятельности и своих трудах Н.Г. Чернышевский выступал как пламенный патриот своей Родины. Он верил в творческие силы русского народа, в светлое будущее России. В «Очерках гоголевского периода русской литературы» он убеждал, что историческое значение каждого человека измеряется его заслугами перед Родиной, силой его патриотизма [21, с. 137].

Свой вклад в понимание патриотизма как нравственной категории внесли такие выдающиеся мыслители России конца XIX - первой половины XX в., как В.С. Соловьев, Н.А. Бердяев, И.А. Ильин и другие. В работе «Русская идея» В.С. Соловьев отмечал: «Проявлять свою мощь, преследовать свой национальный интерес - вот все, что надлежит делать народу, и долг патриота сводится к тому, чтобы поддерживать свою страну и служить ей в этой национальной политике» [16, с. 144]. Для него патриотизм - высший идеал, цель объединения и развития народов, способствующий преодолению национального эгоизма и пороков. 
Религиозный философ Н.А. Бердяев предлагает обратиться к опыту мировой истории; он позволит преодолеть ограниченность национальных интересов и возвысит чувство ценности собственного народа. По его мнению, обязательным условием гармонизации отношений между народами должно стать признание того факта, что «всякая национальность есть богатство единого и братски объединенного человечества, а не препятствие на его пути» [3, с. 93]. Вся жизнь и творчество И.А. Ильина посвящены судьбе России, культуре и менталитету, традициям и самобытности ее народов. «Люди без Родины, - признавался он, - становятся исторической пылью, блеклой осенней листвой, гонимой с места на место и втаптываемой чужеземцами в грязь» $[8$, с. 333$]$.

Для современного бытия России особую актуальность представляют труды Р.Г. Абдулатипова, В. Зорькина, М.Б. Кусмарцева, В.К. Левашова, В.И. Лутовинова, В.В. Макарова, С.М. Рогачева, М.А. Свердлина, А. Халий, Р.Г. Яновского и других. Как считает Р.Г. Абдулатипов, «альтернативы многонациональному правовому федеративному государству в России нет, о чем свидетельствует вся наша многовековая история». Такая модель государственного устройства «позволяет гармонизировать социальное и культурное многообразие страны, учесть специфику потребностей и интересов местных сообществ и повысить степень ответственности перед конкретными гражданами» [1, с. 440].

На специфику региональной ментальности и особенности патриотизма обращает внимание И.А. Халий. Представляя причины размывания ценностей в условиях глобализации и рассматривая специфику местного патриотизма, отношение жителей к родному краю, она выделила три типа отношений к Родине: безоговорочный патриотизм, преобразовательную любовь, индифферентное отношение. По мнению И.А. Халий, исторический опыт показывает, что патриотизм, то есть любовь к «малой родине», как к высшей степени ценности, можно сохранить, только защитив «большую» $[19$, с. 69].

Свой вклад в исследования патриотизма, его ценностей и воспитательного значения вносят волгоградские ученые, в числе которых
А.Н. Вырщиков, Н.В. Дулина, М.Б. Кусмарцев, В.А. Колесников, О.В. Рвачева, А.В. Соловьев. В их трудах патриотизм, как многогранный и исторически сложный феномен, рассматривается сквозь призму тысячелетней истории России, особенно традиций Сталинграда, укрепления государственного и державного могущества страны, обеспечения ее безопасности. В частности, доктор политических наук, профессор В.А. Колесников на нынешнем этапе развития России особое значение придает формированию единой гражданской нации [11, с. 186]. А.Н. Вырщиков и М.Б. Кусмарцев патриотизм определяют как чувство глубокое, древнее, запечатанное в человеческом генотипе, что делает характер данного понятия внеисторичным, его объем наднациональным и метатерриториальным, а содержание кросскультурным, надконфессиональным, надпартийным, надкорпоративным [4, с. 4].

Действительно, патриотизм как феномен является одним из наиболее глубоких исторических чувств, закрепленных в памяти человечества. Однако сложно согласиться с авторами, что он носит внеисторический, надпартийный и иной характер. Исторические факты свидетельствуют о том, что с каждой эпохой патриотизм трансформируется, приобретает качественно новое значение. В течение многих тысяч лет человек не имел представлений о сущности патриотизма. Становление патриотических чувств началось в период разложения первобытных общин; именно тогда стал осуществляться процесс перехода от биологических и этнических форм существования к единому социальному бытию, формирования публичной власти и государства.

Заметим, что процессы социализации, а затем и политизации непрерывно меняют как материальную жизнь общества и людей, так и их сознание. В истории народов период формирования патриотизма можно считать временем перехода от дикости и варварства к цивилизации. Появление патриотизма следует рассматривать как историческую форму выражения объективных интересов. Политическое развитие каждого общества отмечено не только трансформациями социальных систем, но и изменениями целей и ценностей, интересов и потребностей, в том числе в сфе- 
ре культуры, традиций, быта. Признаем, что на каждом историческом этапе функционирования государства, в зависимости от его целей и функций, изменяется сущность и содержание патриотизма; они детерминированы приоритетностью интересов определенных политических и социальных групп, властных элит.

Как свидетельствует история, человеческое общество с момента осознания своих интересов, несмотря на определенное единство, всегда имело классовую структуру, в нем постоянно сосуществовали и одновременно противостояли большие группы (классы) и социальные слои. Поэтому в каждую эпоху патриотизм имел и имеет свой собственный смысл и содержание, потому что он всегда касается как отношений между политическими классами, социальными, этническими и религиозными группами, так и внутри них, становясь часто напряженным, наполненным бесконечной борьбой, конфликтами и войнами.

Результаты. Исследуя патриотизм и специфику патриотического воспитания, отметим ряд следующих проблем и особенностей:

1. Современное политическое бытие Российской Федерации как многонационального и поликонфессионального государства вновь детерминировало актуальные вопросы судьбы нашей цивилизации, поиск общих целей и ценностей, значимость патриотизма и дружбы народов. Патриотизм и вопросы формирования установок патриотического сознания всегда находились и сейчас находятся в компетенции государства и его властных структур, бюрократии, управленческой элиты, как основного субъекта, определяющего реальность и духовно-нравственные основания российской цивилизации. Проблема патриотизма носит системный характер, пронизывает все сферы жизнедеятельности общества и людей, составляет базис социально-культурных отношений. Однако, как показывает практика, до сих пор существует отчуждение между государством и гражданским обществом, властью и личностью, не осуществляется их тесное взаимодействие, реальный диалог и равноправное партнерство; слаба и обратная связь.

2. Патриотизм - историко-политический феномен и социокультурная целостность универсального порядка. Постижение его природы и сущности носит системный характер, значит, наполнение патриотизма современным смыслом и содержанием возможно только с позиций полипарадигмальности, то есть политико-философской методологии. Только с ее помощью возможно осуществление интеграции и синтез всей совокупности знаний о патриотизме из области истории, политологии, социологии, культурологии, этнологии, регионоведения и других наук. Патриотизм следует рассматривать, как «вечную» политическую, социальную, философскую проблему. Значит, каждому поколению людей следует искать «свои», современные ответы на возникающие «вызовы», глобального и партикулярного в мире, взаимодействия власти и общества, политических и социальных групп, находить иные формы и методы реагирования, чем прежде.

3. Патриотизм, национальные интересы и вопросы политики, существования национальных государств оказались в числе актуальных глобальных проблем. Ныне наша цивилизация находится в условиях хаоса и нарастающих рисков, ее развитие характеризуется нелинейностью и неопределенностью. Наверное, следует частично согласиться с американскими учеными С. Хантингтоном и Ф. Фукуямой, прогнозировавшими в конце $\mathrm{XX}$ в., что актуальными в постсовременную эпоху станут процессы различия культур, «столкновения цивилизаций» [20, с. 25], а прежние политические идеологии придадут прошлому свойства «конца истории» $[18$, с. 8]. Следует согласиться с тем, что завершилась прежняя история, она обрела свое окончание; наступила «новая эпоха».

4. Современные методы и формы глобализации мира проблематизировали существование государств и обществ, привели к всплеску этничности и национализма, возродили интерес к национальной и этнической идентичности. Однако нельзя согласиться с тем, что современный период политической динамики, социального развития является временем окончательного господства целей и ценностей либерализма, западного образа жизни, рыночного типа человека. За последние десятилетия, несмотря на популярность идей постмодернизма и абсолютизацию синергетического понимания реальности, для научного сообщества решающим остается естественно-ис- 
торический характер динамики общества. Законы истории, политики объективны, несмотря даже на возрастание в кризисные периоды жизни государства и общества роли стихийности и субъективного фактора.

5. Подлинный патриотизм неразрывно связан с высокой культурой и нравственностью, определенным уровнем образования и воспитания людей, наличием высоких моральных качеств у современного человека. Не секрет, что многие политики и ученые, особенно в западных странах, рассматривают человека в основном, как природно-биологическое существо, абсолютизируют его витальные характеристики. Естественно, что ссылки идут на некую извечную агрессивную природу человека. В этой же плоскости аргументируется неизбежность конфликтов и войн между людьми и народами, представителями разных культур и цивилизаций. Игнорируется системный подход в понимании человека, как единства физического и социокультурного существа, имеющего объективные стремления к жизни в коллективе. Работа по патриотизму и воспитанию людей на принципах дружбы между народами актуальна и в свете разоблачения сущности различных концепций натурализма и биологизма, теорий расизма и национализма. Она требует активного использования положительного потенциала науки, лучших достижений человечества.

6. Сегодня как никогда востребованы не только патриотизм, социальная справедливость, но единство и дружба народов, интернационализм как их неразрывные составляющие. Поэтому важно раскрыть не просто политический смысл и социальное содержание патриотизма, но и пропагандировать идеи интернационализма в нашем полиэтническом и многоконфессиональном обществе, диалектически отрицая прошлое, сохраняя положительный опыт, определяя их как наши общие, единые и неразрывные ценности. Естественно, что формирование высокого уровня политической культуры, общенациональной идентичности возможно только на основе русской цивилизационной доминанты, носителями которой выступают все граждане страны, имеющие такую идентичность независимо от национальности.

7. Патриотизм и интернационализм следует понимать не как противоположности, исключающие друг друга, как принято во многих западных странах. Лишь учитывая смысл и содержание патриотизма в неразрывном единстве с интернационализмом, можно дать объективную оценку многим фактам истории и политическим событиям, понять их роль и место в жизни народов нашей страны. Одновременно такой подход помогает понять глубину и сущность многих процессов, происходящих как в современном российском обществе, так и разных уголках мира, во всей системе международных отношений.

8. Категории «патриотизм» и «интернационализм» в общественном сознании и политической культуре народов России, в отличие от ментальности развитых стран, обладают более глубоким гуманистическим смыслом. На наш взгляд, их следует рассматривать через место и роль России в современной геополитике, сущность «русской идеи», традиций соборности и коллективизма, имеющие для российской цивилизации судьбоносное значение. Неразрывна их связь с категориями «социальное равенство», «социальная справедливость», «совесть». В странах западного мира: Европы, США и других государствах многие ценности воспринимаются в качественно иной плоскости, системе координат. Для них такие понятия, как «равенство», «свобода», «справедливость», «закон» были и остаются в основном правовыми, юридическими категориями. Принципы социального дарвинизма в государствах и обществах Запада считаются естественными и не вызывают сомнений.

9. Для патриотического и интернационального воспитания наших граждан, в частности молодежи, особый характер приобретает политическая история и актуальные проблемы XX века. Это вопросы постижения природы и сущности общественных процессов, особенно сферы рыночных отношений и периодически повторяющихся экономических кризисов. Не менее значимы критика фашизма и нацизма, разоблачения их новых форм, включающих ксенофобию, агрессию и экстремизм. Патриотическая работа предполагает изучение и объективную оценку как мировых войн, революций, трансформаций общественных систем, великих свершений, трагических и драматических эпизодов, так и функционирования политической системы, совре- 
менного многонационального общества, бытия человека. Все более важный характер приобретает необходимость трансформации и модернизация политической системы, всей вертикали власти, признание приоритетности интересов общества, реализация идеи общего блага. Это означает: подчинение государства обществу, принципам подлинной демократии, не формальное провозглашение, а реальное строительство социального государства.

Сегодня в Российской Федерации значимой становится задача по выявлению природы функционирования государства и власти, элит и бюрократии, оценки их деятельности с позиций общенациональных интересов. Для объективного анализа состояния патриотической работы значимо возвращение в категориальный аппарат политологии таких понятий, как «подлинный патриотизм» и «ложный патриотизм». Научному сообществу давно настала пора провести широкий эпистемологический дискурс данных феноменов, наполнить их новым содержанием и политическим смыслом. Ведь не секрет, что «одной из примет современного мира стало возрождение радикализма в самых разнообразных формах - от простой непримиримости оппонентов в различных сферах общественной и индивидуальной жизни, футбольного фанатизма или споров в интернете, до религиозного фундаментализма, терроризма и пр.» [7, с. 91]. Причинами «возрождения» радикализма и экстремизма, ксенофобии и национализма, агрессии и шовинизма стали не только социально-экономические кризисы, но и плюрализм идеологий, толерантность и попустительство со стороны властных структур и этнических элит.

10. Деятельность по патриотическому воспитанию может быть эффективной только при сохранении преемственности, особенно дружбы народов бывшего СССР, придании современного смысла и содержания всему нашему историческому наследию. Соответственно, только тогда объективируется, приобретает истинное значение закрепленное в преамбуле и ст. 3 Конституции РФ 1993 г. интегративное понятие «многонациональный народ», что придаст устойчивый характер развитию страны, откроет новые возможности для формирования единой российской нации $[12$, с. 25$]$. Опора на объективные крите- рии важна не только для сравнительного анализа и оценки прошлого, но и осуществления реальной аналитики настоящего, определения прогнозов, выработки политических сценариев будущего.

11. Использование категорий «общее» и «особенное» позволяет наиболее полно раскрыть роль политики патриотизма и дружбы народов в Победе советского народа в Великой Отечественной войне, объективно и во всей широте показать ее всемирно-историческое значение. Сегодня, несмотря на все сложности, важно выявить и обозначить подлинные интересы как современного российского государства, власти, элиты, так и общества, личности. Естественно, что идеи общего блага и в теории, и политической практике предполагают органическое единство подлинного патриотизма и дружбы народов, интернационализма.

12. Как показывает опыт, успехи в формировании патриотического сознания и пропаганде дружбы народов могут быть достигнуты при высоком творческом отношении к истории, культуре, традициям народов России, но исключительно в единстве с интернациональным воспитанием. Такая общегосударственная парадигма в сфере образования и воспитания, с опорой на единство идей патриотизма и интернационализма, поможет сформировать новую историческую общность людей - единую российскую нацию. Для многонационального и поликонфессионального населения нашей страны вопрос о патриотизме и отношении к интернационализму - это в сущности вопрос совместного бытия России, ее настоящего и будущего, уровня развитости политического сознания и политической культуры общества, специфики его культурного и нравственного развития, способности к сплочению и единству, реализации общенациональных интересов.

Как известно, несколько лет назад Президентом РФ В.В. Путиным город-герой Волгоград объявлен центром патриотического воспитания. Действительно, за последние десятилетия в Волгоградской области проведена большая работа по патриотическому и интернациональному воспитанию. Например, в результате тесного взаимодействия Комитета по делам национальностей и казачества 
региона, общественной организации и Совета старейшин «Дома Дружбы», председателей национальных общин, с участие большого количества населения, особенно молодежи, проводятся знаменательные даты - годовщины Сталинградской битвы, Великой Победы, День города, День народного единства. Тема патриотизма, сохранения и укрепления дружбы народов всегда в центре внимания проходящих в Волгограде фестивалей и праздников национальных культур: азербайджанской, еврейской, корейской, осетинской, польской, татарской, таджикской, узбекской. Вопросы патриотического воспитания, сохранения и развития общенационального единства страны постоянно обсуждаются на «круглых столах», семинарах, встречах ученых и руководителей национальных и религиозных общественных организаций со студентами волгоградских высших учебных заведений.

13. Феномен патриотизма является основой политической социализации, формирования общей культуры, единой российской нации; он должен превратиться в органическую часть жизнедеятельности многонационального народа России. Это не только забота о хлебе насущном, важной для значительной части населения, жажда политических свобод и обеспеченности материальными благами. Она касается физического и нравственного здоровья людей, повседневной жизнедеятельности человека, культуры, отношений к истории, ценностям и традициям. Забота обо всем этом является не только формой проявления гуманизма, она имеет и патриотическое содержание. Не следует забывать, что окружающий человека мир в его обыденном сознании предстает, прежде всего, в образе родной земли, родного очага, этнических и национальных ценностей, традиций, созданных народом и существующих веками.

Поэтому не случайно, что «с учетом современных задач развития Российской Федерации целью государственной политики в сфере патриотического воспитания является создание условий для повышения гражданской ответственности за судьбу страны, повышения уровня консолидации общества для решения задач обеспечения национальной безопасности и устойчивого развития Российской Федерации, укрепления чувства сопричастно- сти граждан к великой истории и культуре России, обеспечения преемственности поколений россиян, воспитания гражданина, любящего свою Родину и семью, имеющего активную жизненную позицию» $[14$, с. 3$]$.

Опыт политического и общественного развития свидетельствует, как и насколько высокие и благородные цели патриотизма влияют на динамику человеческого общества, социальный прогресс, когда они освобождаются от расизма и национализма, шовинизма и экстремизма, когда они соединяются с идеями интернационального единства и дружбы народов.

Подводя итоги, отметим, что российский суперэтнос объединяет народы, принадлежащие к разным типам цивилизаций и культур. Общность исторической судьбы, близость мировоззрений и поведенческих стереотипов позволили сформировать единое социокультурное пространство [6, с. 339]. За столетия во взаимоотношениях народов России сложился естественный динамический баланс, обеспечивший внутреннюю прочность их союза. Только учет прошедших проверку временем и оправдавших себя идей и традиций, в числе которых такие детерминанты, как патриотизм и дружба народов, способны усилить интеграционные тенденции и создать новые возможности для совместной деятельности ради нашего общего будущего.

\section{СПИСОК ЛИТЕРАТУРЫ}

1. Абдулатипов, Р. Г. Национальный вопрос и государственное устройство России / Р. Г. Абдулатипов. - М. : Славянский диалог, 2000. -656 с.

2. Белинский, В. Г. Статьи о Пушкине, Лермонтове, Гоголе / В. Г. Белинский. - М. : Просвещение, 1983. $-272 \mathrm{c}$.

3. Бердяев, Н. А. Судьба России: опыты по психологии войны и национальности / Н. А. Бердяев. - М. : Мысль, 1990. -240 с.

4. Вырщиков, А. Н. Патриотическое воспитание молодежи в современном российском обществе / А. Н. Вырщиков, М. Б. Кусмарцев. - Волгоград : Авторское перо, 2006. - 186 с.

5. Гегель, Г. В. Ф. Философская пропедевтика / Г. В. Ф. Гегель // Работы разных лет : в 2 т. Т. 2. М. : Мысль, 1971. - С. 7-209.

6. Данакари, Р. А. Философия этнического бытия. Этническая группа удин(ы) в условиях гло- 
бализации человечества / Р. А. Данакари. - Волгоград : Изд-во Волгогр. ин-та управления - филиала ФГБОУ ВО РАНХиГС, 2017. - 388 с.

7. Емелин, В. А. Современный радикализм: феноменология, происхождение, механизмы / В. А. Емелин, А. Ш. Тхостов // Вопросы философии. - 2019. № 7. - С. 89-98,

8. Ильин, И. Мы были правы / И. Ильин // И. Ильин. О грядущей России. - М. : ЛИАНА, 1993. $-363 \mathrm{c}$.

9. Кант, И. Метафизика нравов в двух частях / И. Кант // Сочинения : в 6 т. - М. : Мысль, 1965. Т. 4, ч. 2. - С. 107-438.

10. Карамзин, Н. М. Антология педагогической мысли России первой половины ХІХ в. (до реформ 60-х гг.) / Н. М. Карамзин. - М. : Педагогика, 1987. $-560 \mathrm{c}$.

11. Колесников, В. А. Российская нация и многонациональный народ / В. А. Колесников // Теории и проблемы политических исследований. 2018. - T. 7, № 5A. - С. 184-192.

12. Конституция Российской Федерации: принята всенародным голосованием 12.12.1993. - Электрон. текстовые дан. - Режим доступа: http://www. consultant.ru/document/consdocLAW28399/ (дата обращения: 21.01.2019). - Загл. с экрана.

13. Ломоносов, М. В. О воспитании и образовании / М. В. Ломоносов ; сост. Т. С. Буторина. М. : Педагогика, 1991.-339, [4] с.

14. Постановление Правительства РФ от 30 декабря 2015 г. № 1493 «О государственной программе "Патриотическое воспитание граждан Российской Федерации на 2016-2020 годы”». С изм. и доп. от 13 октября 2017 г. - Электрон. текстовые дан. - Режим доступа: http://base. garant.ru/71296398/ (дата обращения: 21.01.2019). Загл. с экрана.

15. Радищев, А. Н. Полное собрание сочинений : в 2 т. Т. 1 / А. Н. Радищев. - М. ; Л. : Изд-во Акад. наук СССР, 1938. -503 с.

16. Соловьев, В. С. Русская идея / В. С. Соловьев. - М. : Республика, 1992. - 496 с.

17. Философский энциклопедический словарь / Л. Ф. Ильичев, П. Н. Федосеев, С. М. Ковалев, В. Г. Панов. - М. : Сов. энцикл., 1983. - 840 с.

18. Фукуяма, Ф. Конец истории и последний человек / Ф. Фукуяма. - М. : АСТ, 2015. - 576 с.

19. Халий, И. А. Патриотизм в России: опыт типологизации / И. А. Халий // СОЦИС. - 2017. № 2. - С. 67-74.

20. Хантингтон, С. Столкновение цивилизаций / С. Хантингтон. - М. : АСТ, 2003. - 603 с.

21. Чернышевский, Н. Г. Очерки гоголевского периода русской литературы / Н. Г. Чернышевский. - М. : ОГИЗ. Гос. изд-во худож. лит., 1947. T. 3. $-884 \mathrm{c}$.

\section{REFERENCES}

1. Abdulatipov R.G. Natsionalnyy vopros $i$ gosudarstvennoe ustroystvo Rossii [National Issue and State Structure of Russia]. Moscow, Slavyanskiy dialog Publ., 2000. 656 p.

2. Belinskiy V.G. Statyi o Pushkine, Lermontove, Gogole [Articles About Pushkin, Lermontov, Gogol]. Moscow, Prosveshchenie Publ., 1983. 272 p.

3. Berdyaev N.A. Sudba Rossii: opyty po psikhologii voyny $i$ natsionalnosti [The Fate of Russia: Experiments on the Psychology of War and Nationality]. Moscow, Mysl Publ., 1990. 240 p.

4. Vyrshchikov A.N., Kusmartsev M.B. Patrioticheskoe vospitanie molodezhi v sovremennom rossiyskom obshchestve [Patriotic Education of the Youth in Modern Russian Society]. Volgograd, Avtorskoe pero Publ., 2006. 186 p.

5. Gegel G.V.F. Filosofskaya propedevtika [Philosophical Propaedeutics]. Raboty raznykh let: v 2 t. T. 2 [Works of Different Years: In 2 Vols. Vol. 2]. Moscow, Mysl Publ., 1971, pp. 7-209.

6. Danakari R.A. Filosofiya etnicheskogo bytiya. Etnicheskaya gruppa udin(y) v usloviyakh globalizatsii chelovechestva [The Philosophy of Ethnic Life. Ethnic Group of Udin(s) in the Context of Globalization of the Mankind]. Volgograd, Izd-vo Volgogradskogo instituta upravleniya - filiala FGBOU VORANKhiGS, 2017. 388 p.

7. Emelin V.A., Tkhostov A.Sh. Sovremennyy radikalizm: fenomenologiya, proiskhozhdenie, mekhanizmy [The Modern Radicalism: Phenomenology, Origin and Mechanisms]. Voprosy filosofii, 2019, vol. 7, pp. 89-98.

8. Ilyin I. My byli pravy [We Were Right]. O gryadushchey Rossii [About the Upcoming Russia]. Moscow, LIANA Publ., 1993. 363 p.

9. Kant I. Metafizika nravov v dvukh chastyakh [Metaphysics of Morals in Two Parts]. Sochineniya: $v 6 t$. [Works: In 6 Vols.], vol. 4, part 2, pp. 107-438.

10. Karamzin N.M. Antologiya pedagogicheskoy mysli Rossii pervoy poloviny XIX v. (do reform 60-kh gg.) [Anthology of Pedagogical Thought of Russia in the First Half of the $19^{\text {th }} \mathrm{c}$. (Before the Reforms of the 60s)]. Moscow, Pedagogika Publ., 1987. 560 p.

11. Kolesnikov V.A. Rossiyskaya natsiya i mnogonatsionalnyy narod [Russian Nation and Multinational People]. Teorii $i$ problemy politicheskikh issledovaniy [Theories and Problems of Political Research], 2018, vol. 7, no. 5A, pp. 184-192.

12. Konstitutsiya Rossiyskoy Federatsii: prinyata vsenarodnym golosovaniem 12.12.1993 [Constitution of the Russian Federation. Adopted by the National Referendum]. URL: http://www. consultant.ru/document/cons doc LAW 28399/ (accessed 21 January 2019). 
13. Lomonosov M.V., Butorina T.S., ed. $O$ vospitanii i obrazovanii [About Upbringing and Education]. Moscow, Pedagogika Publ., 1991. 339, [4] p.

14. Postanovlenie Pravitelstva RF ot 30 dekabrya 2015 g. № 1493 «O gosudarstvennoy programme "Patrioticheskoe vospitanie grazhdan Rossiyskoy Federatsii na 2016-2020 gody" ". S izm. $i$ dop. ot 13 oktyabrya $2017 \mathrm{~g}$. [Resolution of the Government of the Russian Federation of December 30, 2015 no. 1493 "On the State Program 'Patriotic Education of Citizens of the Russian Federation for 2016-2020" as Amended and Supplemented of October 13, 2017]. URL: http://base.garant.ru/ 71296398/ (accessed 21 January 2019).

15. Radishchev A.N. Polnoe sobranie sochineniy: $v 2 t$. [Full Collection of Writings: In 2 Vols.]. Moscow; Leningrad, Izd-vo Akademii nauk SSSR, 1938, vol. $1.503 \mathrm{p}$.
16. Solovyev V.S. Russkaya ideya [Russian Idea]. Moscow, Respublika Publ., 1992. 496 p.

17. Ilyichev L.F., Fedoseev P.N., Kovalev S.M., Panov V.G. Filosofskiy entsiklopedicheskiy slovar [Philosophical Encyclopedic Dictionary]. Moscow, Sovetskaya ehntsiklopediya Publ., $1983.840 \mathrm{p}$.

18. Fukuyama F. Konets istorii i posledniy chelovek [The End of History and the Last Man]. Moscow, AST Publ., 2015. 576 p.

19. Khaliy I.A. Patriotizm v Rossii: opyt tipologizatsii [Patriotism in Russia: Experience of Typology]. SOTSIS [Socis], 2017, no. 2, pp. 67-74.

20. Khantington S. Stolknovenie tsivilizatsiy [Clash of Civilizations]. Moscow, AST Publ., 2003. 603 p.

21. Chernyshevskiy N.G. Ocherki gogolevskogo perioda russkoy literatury [Essays on the Gogol Period of Russian Literature]. Moscow, OGIZ. Gosudarstvennoe izd-vo khudozhestvennoy literatury, 1947, vol. 3. 884 p.

\section{Information about the Author}

Richard A. Danakari, Doctor of Sciences (Philosophy), Professor, Department of Philosophy and Sociology, Volgograd Institute of Management, Branch of Russian Presidential Academy of National Economy and Public Administration, Gagarina St., 8, 400131 Volgograd, Russian Federation, rdanakari@mail.ru, https://orcid.org/0000-0001-5683-5275

\section{Информация об авторе}

Ричард Арами Данакари, доктор философских наук, профессор кафедры философии и социологии, Волгоградский институт управления - филиал Российской академии народного хозяйства и государственной службы при Президенте РФ, ул. Гагарина, 8, 400131 г. Волгоград, Российская Федерация, rdanakari@mail.ru, https://orcid.org/0000-0001-5683-5275 